\title{
Energy Consumption, Economic Growth And Environmental Sustainability Challenges For Belt And Road Countries: A Fresh Insight From "Chinese Going Global Strategy"
}

Abdul Jalil ( $\square$ jalil_ahmed21@yahoo.com )

Nanjing University of Information Science and Technology Binjiang College https://orcid.org/00000002-4317-8226

Abdul Rauf

Nanjing University of Information Science and Technology

Waqas Sikander

University of the Punjab Quaid-i-Azam Campus: University of the Punjab

\section{Zhang Yonghong}

Nanjing University of Information Science and Technology Binjiang College

Wang Tiebang

Nanjing University of Information Science and Technology Binjiang College

\section{Research Article}

Keywords: Energy consumption, Economy, Environment, Belt and Road Initiative, Sustainable development, Carbon Dioxide

Posted Date: June 15th, 2021

DOI: https://doi.org/10.21203/rs.3.rs-573704/v1

License: (c) (i) This work is licensed under a Creative Commons Attribution 4.0 International License. Read Full License

Version of Record: A version of this preprint was published at Environmental Science and Pollution Research on July 29th, 2021. See the published version at https://doi.org/10.1007/s11356-021-15549-z. 


\section{Energy consumption, Economic growth and Environmental Sustainability} Challenges for Belt and Road Countries: A Fresh Insight from "Chinese Going Global Strategy"

Abdul Jalil ${ }^{\mathrm{a}^{*}}$, Abdul Rauf $\mathrm{f}^{* *}$, Waqas Sikander ${ }^{\mathrm{c}}$, Zhang Yonghong $^{\mathrm{a}}$, Wang Tiebang ${ }^{\mathrm{a}}$

${ }^{a}$ Binjiang College, Nanjing University of Information Science and Technology, 333, Xishan road, Wuxi, 214105, China

${ }^{b}$ School of Management Science and Engineering, Nanjing University of Information Science and Technology, Nanjing, 210044, China

${ }^{c}$ College of Earth and Environmental Science, University of the Punjab, New Quaid-e-Azam campus, Lahore, Pakistan

Corresponding Authors:

*Abdul Jalil

Binjiang College, Nanjing University of Information Science and Technology, No 333, Xishan road, Wuxi city, Jiangsu, 214105, China

Tel: +86-15905173417

E-mail: jalil_ahmed21@hotmail.com

**Abdul Rauf

School of Management and Engineering, Nanjing University of Information Science and

Technology, 219, Ningliu Road, Nanjing, Jiangsu, 210044, China

Tel: +86-13770641422

E-mail: abdulrauf@seu.edu.cn 
Abstract

The present study investigated impact of energy and economy related variables on $\mathrm{CO}_{2}$ emissions in 49 countries of belt and road initiative from 1995-2018. The robust type of crosssection dependence and heterogeneity methods were adopted to analyze data set of countries. Energy consumption, foreign direct investment, medium and high-tech industry, and GDP has been found highly unfavorable for the ecological health $\left(\mathrm{CO}_{2}\right.$ emissions) in 49 nations on BRI panel. However, renewable energy consumption has been found in positive correlation with environmental quality $\left(\mathrm{CO}_{2}\right)$. Financial development indicator has no significant impact on $\mathrm{CO}_{2}$ emissions in present study. The present outcomes clearly claim strong relationship of economic growth and energy with increased $\mathrm{CO}_{2}$ emissions in 49 nations. Therefore, it is important for policy makers, experts and governments to incentivize and appreciate portfolio investors for sustainable green investments to transform the economic growth into a sustainable and energy efficient development.

Keywords: Energy consumption; Economy; Environment; Belt and Road Initiative; Sustainable development; Carbon Dioxide 


\section{Declaration}

Ethics approval and consent to participate: Not Applicable

\section{Consent for publication: Not Applicable}

Availability of data and materials: The datasets generated and/or analysed during the current study are available in the [World Bank] repository, [https://databank.worldbank.org/source/world-development-indicators\#]

Competing interest: The authors declare that they have no competing interest.

Funding: "The study is supported by Startup foundation for introducing Foreign Talent (Changwang high level talents) for Binjiang college of Nanjing University of Information Science and Technology, (NUIST), P.R.China (EMP\#100003); startup foundation for introducing Talent of Nanjing University of Information Science and Technology, (NUIST), P.R.China (EMP\#003203)".

Authors' contributions: Conceptualization from Abdul Jalil and Abdul Rauf; Data curation done by Waqas sikander and Abdul Rauf; Formal analysis completed by Waqas Sikander and Wang Tiebang; Methodology done by Abdul Jalil, Abdul Rauf, Waqas Sikander and Wang Tiebang; Project administration, Zhang Yonghong; Resources, Zhang Yonghong; Software, Abdul Rauf and Wang Tiebang; Supervision, Zhang Yonghong; Writing - original draft done by Abdul Jalil and Waqas Sikander; Writing - review \& editing, Abdul Rauf and Wang Tiebang. All authors read and approved the final manuscript.

Acknowledgments: The authors wish to thank to the responsible editor and reviewers for their constructive and valuable comments for enhancing the quality of our manuscript. 


\section{Introduction}

In the current era of development and modernization, climate change is the biggest threat particularly to the human beings and earth ecosystem in total. Global emissions of Greenhouse gases (GHGs), Carbon dioxide, and rise in atmospheric temperature are being considered as the core reasons of the global climate change (IPCC 2014). The $21^{\text {st }}$ Conference of Parties (December 2015) held in Paris reached at an agreement called "Paris agreement" which emphasis on the limiting of global warming to well below $2{ }^{\circ} \mathrm{C}$ and working on developing strategies for long term reduction of greenhouse gases to achieve long term goals of Paris agreement (UNFCCC. 2018). The international trade has implications on the environment, which ultimately plays its role in global climate change (Cai et al. 2018).

The "Belt and Road (BRI)" is an initiative taken by Chinese government to develop international cooperation and economic strategy (Chen 2016, Rauf et al. 2020). This initiative has main goals to cover international trade, infrastructural and financial connectivity among partner countries, policies integration and coordination, sharing technologies for the development and economic advancement of partner countries around the globe (Finance 2021, Intelligence 2017). BRI has potential to develop a unified world trade partnership along with a strong geopolitical coalition, which will bring a common future for all partner nations (Ho 2017). The projects under BRI will have strong impact on the economic development of the partner economies (Yii et al. 2018), through trade extension, access to advanced markets, shared skills, technologies and manpower, and inflow of funds towards the under developed, developing and emerging countries (Economy 2017). The Ministry of Ecology and Environment of China issued guidelines in 2017 for promoting "Green Belt and Road". Later on, mentioned Chinese ministry initiated "BRI International Green Development Coalition" focusing on green initiative (finance, 
transport, innovation, urbanization and standards). They are mainly addressing the five goals of BRI initiative with the green development concept (Finance 2021). Along with advancement in infrastructure, economic and trade cooperation with developing and developed countries (Du \&Zhang 2018), the climate change related issues and energy cooperation are major concerns of China while expanding BRI projects range (Zhang et al. 2017b). European Union (EU) and China in this regard showed strong commitment on clean energy (Zhang 2021) and climate change(Torney \&Gippner 2018) through intensifying economic, political and technical cooperation (Liu \&Hao 2018).

The energy growth has strong correlation with financial development (here in the sense of economic growth) and environmental change which can be found in literature. As, Grossman and Krueger (Grossman \&Krueger 1995) testified the three stages of Environmental Kuznet curve (EKC) (Kuznets 1955) where first phase focusses on evolution of economy along with policy formulations while neglecting the ecological impacts of the development. Second phase shows the intensified emissions of $\mathrm{CO}_{2}$ due to economic evolution while third phase is about realization of damage and adaptation of environment friendly policies and technologies to minimize the environmental impact. Many researchers around the globe tested EKC hypothesis and found a strong liaison between economic development and emissions of $\mathrm{CO}_{2}$. Toman andJemelkova (2003) tested 25 OECD countries, Musolesi et al. (2010) tested 106 countries, Jaunky (2011) tested 36 high income countries; Apergis andOzturk (2015) tested 14 Asian countries. All aforementioned studies approved EKC hypothesis and found that emissions of $\mathrm{CO}_{2}$ have strong long-term relationship with economic growth. Balsalobre-Lorente et al. (2018) also investigated the economic advancement relationship with emissions of $\mathrm{CO}_{2}$ that was $\mathrm{N}$ shaped nexus between them in 5 European countries. 
Ayeche et al. (2016) investigated 40 European economies and found a strong linkage between GDP, financial development, trade openness and emissions of $\mathrm{CO}_{2}$. In case of China, $\mathrm{Xu}$ andLin $(2016 \mathrm{a}, \mathrm{b})$ found that rapid industrialization and economic development are the key factors behind $\mathrm{CO}_{2}$ emissions in China. But Dombrowski (2017) warned that BRI projects will transfer the $\mathrm{CO}_{2}$ emitting industries and businesses to other BRI partner countries, relieving china in a better state without having severe environmental impacts on it. The Statistical review by British Petroleum (Petroleum 2017) showed that BRI partner countries are contributing around $61.4 \%$ of $\mathrm{CO}_{2}$ emissions among which $80 \%$ is energy consumption based emissions, that leading to global ecological deterioration impacts. Rauf et al. (2018a) also mentioned that BRI host countries might face severe natural resources deterioration effects along with stern impacts on their culture and ecology. Figure 1 shows the investments of china in BRI partner nations and $39.3 \%$ of those investments belongs to the energy sector.

The BRI projects can have impacts of accelerated global warming due to increased infrastructural, energy generation and trade activities (Fan et al. 2017, Zhao et al. 2016). On the other hand, it could also be an opportunity to minimize the global $\mathrm{CO}_{2}$ emissions and to improve the quality of environment while implementing BRI in the partner countries (Zhang et al. 2017a). It is possible especially through empowering developing countries having abundant renewable resources but do not have sufficient technological and financial equipment to utilize those resources (Schwerhoff \&Sy 2017). The BRI could also serve as a platform for the partner countries to take joint action against $\mathrm{CO}_{2}$ emissions (Zhang et al. 2018). There has been highly sophisticated research been done on the economic, trade and international cooperation impacts of BRI on partner countries in particular and on the world in general. But it is a dire need to do the research on the long-term climate change related impacts of BRI in the partner countries and also 


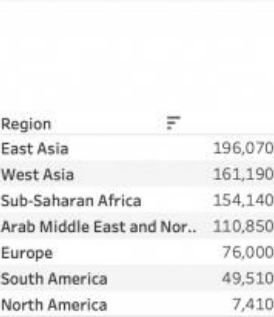

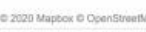

Sector split

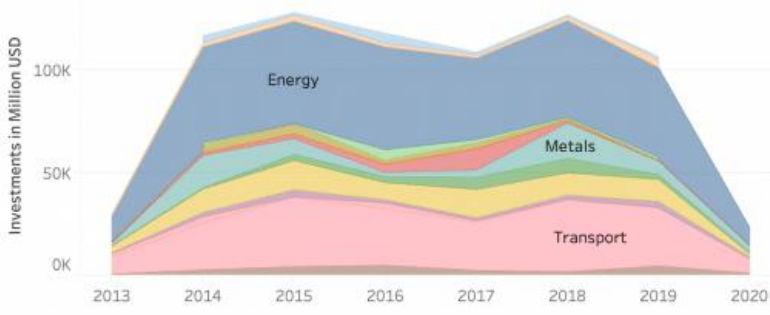

(c) Copyright 2020 Green BRI Center, International Institute of Green Finance (IIGF), Beijing Data: American Enterprise Institute (AEI), China Investment Tracker, 2020

\section{Materials and Methods}

on the global warming. Therefore, the present study objectives are; to investigate the impacts of energy consumption, economic growth and other developmental parameters on the emissions of $\mathrm{CO}_{2}$ in BRI partner countries; and to evaluate the linkages between economic growth, environmental sustainability and energy growth factors in BRI countries.

Figure 1: Investments of China in BRI countries from 2013-H12020 (million USD) ${ }^{1}$

\subsection{Data and Variables}

This study contemplates BRI-associated nations in the terrestrial locations of Europe, East Asia, Pacific, Central Asia, South Asia, Middle East and North Africa. There were 49

1 Source: https://green-bri.org/wp-content/uploads/2020/09/Investments-in-the-Belt-and-Road-InitiativeBRI-2020-1024x614.png 


\begin{tabular}{ll}
\hline Variables & Description \\
\hline Energy consumption (EC) & Litres to kilograms energy usage per capita \\
\hline Carbon emission $\left(\mathrm{CO}_{2}\right)$ & $\begin{array}{l}\text { Metric tones of } \mathrm{CO}_{2} \text { atmospheric release per } \\
\text { capita }\end{array}$ \\
\hline Foreign Direct Investment (FDI) & $\begin{array}{l}\text { Percent of GDP (total inflow of foreign direct } \\
\text { investment) }\end{array}$ \\
\hline Trade friendliness/openness (TOP) & Trade (\% of GDP) \\
\hline Financial development (FD) & Percent of GDP (private sector domestic credit) \\
\hline Industry (medium and high-tech) (MHI) & MHI as percent of value added manufacturing \\
\hline Renewable energy consumption (REC) & $\begin{array}{l}\text { REC as percent of total final energy } \\
\text { consumption }\end{array}$ \\
\hline Gross domestic product (GDP) & $\begin{array}{l}\text { GDP per capita with a constant o 2010 US } \\
\text { dollars }\end{array}$ \\
\hline 2
\end{tabular}

\subsection{Steps for Econometric analyses}

\footnotetext{
${ }^{2}$ Source: https://data.worldbank.org/
} 
To test the hypothesis for the underlying variables, i.e., $\mathrm{CO}_{2}$, ECON, FD, GDP, FDI, MHI, TOP, and REC a primary equation is formed (Equation-1). Based on several recent studies e.g. (Al-Mulali et al. 2015, Behera \&Dash 2017, Doğan et al. 2021, Gulistan et al. 2020, Haseeb \&Azam 2020, Khan et al. 2020, Khan et al. 2019, Rauf et al. 2020, Saboori \&Sulaiman 2013) the following relationship among variables under investigation in this study has been developed;

$$
\mathrm{CO}_{2}=f(E P C, F D, G D P, \mathrm{FDI}, M H I, T O P, R E C,)
$$

Here in Eq. 1, Carbon dioxide as mentioned earlier is the dependent variable and relationship will be estimated as " $\mathrm{CO}_{2}$ is equal to the function of independent variables". The econometric analysis for this study comprises the following steps. (i) Analysis of the descriptive statistics such as correlation analysis for the selected variables for this study. (ii) Testing the dependence (cross-sectional) of the countries data to confirm that the estimate drawn from the dataset is reliable. Afterwards, co-integration checkup based on the results can verify long-run integrated forms amongst the variables (Al-Mulali et al. 2013). (iii) Fully Modified OLS (FMOLS) and Dynamic OLS (DOLS) models for equilibrium relationships. Finally, (iv) The Panel Heterogeneous Granger causality test will be used to detect interconnectivity as used by Rauf et al. (2018a).

Equation 1 is an appropriate representation of the base model. The base model is rewritten with the natural log form of data and equation 2 is formed.

$$
\begin{gathered}
\mathrm{CO}_{2, \mathrm{t}}=\alpha+\beta_{1} \operatorname{lnECON}_{\mathrm{i}, \mathrm{t}}+\beta_{2} \ln \mathrm{FD}_{\mathrm{i}, \mathrm{t}}+\beta_{3} \operatorname{lnGDP}_{\mathrm{i}, \mathrm{t}}+\beta_{4} \ln \operatorname{lnDI}_{\mathrm{i}, \mathrm{t}}+\beta_{5} \operatorname{lnMHI}_{\mathrm{i}, \mathrm{t}}+\beta_{6} \operatorname{lnTOP}_{\mathrm{i}, \mathrm{t}} \\
+\beta_{7} \operatorname{lnREC_{i,\mathrm {t}}}+\varepsilon_{\mathrm{i}, \mathrm{t}}
\end{gathered}
$$


Whereas, $\mathrm{i}=$ number of countries, $\mathrm{t}=$ time, $\ln =$ natural logarithm, $\alpha=$ intercept, $\beta=$ slope to the parameters, and $\varepsilon i, \mathrm{t}=$ error terms for the equation.

\subsubsection{Dependency test (Cross-sectional)}

Testing cross-sectional dependency of variables is critical to form any econometric model. Cross-sectional dependence (CD) is an important test in large data econometric modeling. It should be checked by investigators before evaluating investigation of any group. The existence or not of such a violation will correct the auxiliary path, which must be followed later. If the information in the dataset has a cross-sectional dependency, the other phases of the analysis should retain tests that are consistent with the cross-sectional dependency.

In structured variables, the cross dependence based on residuals can be examined by LM test (Breusch \&Pagan 1980), scaled LM test (bias-corrected) (Baltagi et al. 2012) and CD test (Pesaran 2004). "No" cross-sectional dependence among that residual based dataset is the Null hypothesis.

Therefore, both the CD and LM test are structured in the following ways:

$$
\begin{aligned}
& L M=\sqrt{\frac{2 T}{N(N-1)}}\left(\sum_{i=1}^{N-1} \sum_{j=i+1}^{N} \hat{\rho}_{i j}\right) \frac{(T-k) \hat{\rho}_{i j}^{2}-E(T-k) \hat{\rho}_{i j}^{2}}{\operatorname{Var}(T-k) \hat{\rho}_{i j}^{2}} \\
& C D=\sqrt{\frac{2 T}{N(N-1)}}\left(\sum_{i=1}^{N-1} \sum_{j=i+1}^{N} \hat{\rho}_{i j}\right) \sim N(0,1) i, j=1,2,3 \ldots 65 \ldots N
\end{aligned}
$$


Whereas, $\hat{\rho}_{i j}^{2}$ is residuals correlation, which was valued by using Ordinary Least Square equation. The results of the above given equations are given below in Table 2 with $1 \%$ level of significance for Null hypothesis $\left(\mathrm{H}^{0}\right)$.

Table.2 Results of (CD) Test

\begin{tabular}{|l|l|}
\hline Test & Statistic \\
\hline LM of Breusch-Pagan & $11392.35^{* * *}$ \\
\hline LM of Pesaran scaled & $210.6577^{* * *}$ \\
\hline Bias-corrected scaled LM & $209.6777^{* * *}$ \\
\hline CD by using Pesaran & $73.54330^{* * *}$ \\
\hline
\end{tabular}

${ }^{1}$ Note: “***” represent $1 \%$ level of significance.

The cross dependence of the dynamic panels for residuals of dataset has been investigated by using CD tests of Frees (Frees 1995, 2004) Friedman (1937) and Pesaran (2004).

The short term and large cross-sectional residual dependence for given dataset (time and number of countries) gave a clear understanding about the relationship between the countries over the given time period. The results (Table 3) of these tests rejected Null hypothesis of cross-section independence.

Table.3 Results of (CD) test of the residuals

\begin{tabular}{|l|l|}
\hline Test & Statistic \\
\hline Pesaran CD test & $73.54330^{* * *}$ \\
\hline Friedman test & $265.9161^{* * *}$ \\
\hline Frees test & $7.504881^{* * *}$ \\
\hline
\end{tabular}

${ }^{1}$ Note: “***” represent $1 \%$ level of significance. 


\subsubsection{Unit Root Tests}

The unit root tests are of two types. First type considers the self-determining power of $\mathrm{CD}$ of target countries. The $2^{\text {nd }}$ type/generation test allows the $\mathrm{CD}$ of the countries. The current study used both types of unit root tests to provide strong justification of stability in the results. The current panel's data acknowledges that there are longer-term events, which could increase the degree of independence (d.f) and exacerbate the multidimensional crisis to assess the equation of OLS. Therefore, panel data can withstand more compelling scientific techniques and asymptomatic statistics, which follow a general distribution rather than a noise distribution.

Choi(Choi 2006) deviced the panel unit root test with opposite assumption/hypothesis like Hadri (2000). Levin et al. (2002) used restricting type of panel unit root test for samples of the finite properties while Im et al. (2003) also advised heterogenous panel unit root test.

Therefore, this study applies the LLC, IPS, and ADF Fisher Chi-square test for testing the unit root (Table 10) to hold the order of cointegration among the variables under this study. In this connection, the panel unit root test of IPS is depicted with the following equation:

$$
\Delta y_{i, t}=\alpha_{i}+\beta_{i} y_{i, t-1} \sum_{j=1}^{p i} \rho_{i j} \Delta y_{i, t-j}+\varepsilon_{i, t} \quad i=1, \ldots t=1, \ldots T
$$

Equation 5 above depicts $y_{i, t}$ as the dataset containing $i$ countries for $t$ time but the lag operators are denoted with " $\Delta$ ". Here, $\varepsilon_{i, t}$ stands for the error term for the normally distributed sample BRI countries.

The results (Table 2 and Table 3) show the cross dependence in the dataset. Therefore, we need to apply $2^{\text {nd }}$ type of CD tests to justify the hitch of cross-dependence. Pesaran(Pesaran 
2007) defined the process of cross-sectional Im, Pesaran, and Shin (CIPS) and cross-sectional augmented Dickey-Fuller (CADF). The country to county cross-sectional dependence, reliability and steadfastness will be the outcomes of these two methods with their natural heterogeneity.

Therefore, the test may further be built as follows:

$$
\Delta y_{i, t}=c_{i}+\alpha_{i} y_{i, t-1}+\beta_{i} \bar{y}_{t-1}+\sum_{j=0}^{p} \gamma_{i j} \Delta \bar{y}_{i, t-j}+\sum_{j=1}^{p} \delta_{i j} \Delta \bar{y}_{i, t-j}+\eta_{i, t} \quad i=1, \ldots n
$$

Whereas; $c_{i}=$ constant, $\bar{y}=$ mean of cross-section at " $t$ " period, and $p=$ lag operator.

Supposing $t_{i}$ (N, TM) same as the time ratio of $\alpha_{i}$, the mean of t-ratios (time ratios) will be as follows;

$\operatorname{CIPS}\left(N, T_{m}\right)=\frac{\sum_{i=1}^{N} t_{i,}\left(N, T_{m,}\right)}{N}$

Here, $t_{i,}\left(N, T_{m}\right)$ is Augmented Dickey-Fuller (CADF) indicators for the $i^{\text {th }}$ cross-sections.

\subsubsection{Co-integration Tests}

The results of both types of unit root tests approved the stability of dataset. Cointegration tests by Pedroni (1999), (Pedroni 2004) can further validate the level of cointegration. Robustness can be confirmed by using Wetserlund co-integration test (Westerlund 2007) to get dependency of cross sections. The base of co-integration test is Engle-Granger (a typical unit root test) which has been further expanded by Westerlund et al. (2015). Also see (AlMulali et al. 2012, Ciarreta \&Zarraga 2010 (Khan et al. 2017, Rauf et al. 2018a) for the purpose of determining long-run connectivity between candidate variables. Therefore, it has been verified that all given variables together formulated into first order (Equation 1). 
Likewise, The Pedroni cointegration test augmented the following equation:

$$
\begin{gathered}
\operatorname{CO2}_{i, t}=\alpha+\delta_{i} t+\beta_{1} \operatorname{lnECON}_{i, t}+\beta_{3} \operatorname{lnF} D_{i, t}+\beta_{2} \operatorname{lnGDP} P_{i, t}+\beta_{4} \operatorname{lnFDI} I_{i, t}+\beta_{5} \operatorname{lnMHI}_{i, t}+ \\
+\beta_{5} \operatorname{lnTOP} P_{i, t}+\beta_{5} \operatorname{lnREC} C_{i, t}+\varepsilon_{i, t} \\
i=1, \ldots \quad t=1, \ldots T
\end{gathered}
$$

Whereas, $\boldsymbol{\alpha}_{\boldsymbol{i}}$ is constant for each country, and $\boldsymbol{\delta}_{\boldsymbol{i}} \boldsymbol{t}$ is the full panel deterministic trends of the particular country. There were eleven statistical results of the Pedroni co-integration test while investigating both hypotheses. $\boldsymbol{\beta}_{\mathbf{1}}$ is homogenous for null hypothesis and its heterogeneous for alternative hypothesis. The co-integration among variables can be seen in Table 9. The uniformity between the target variables has been found normally distributed, which verifies the Pedroni co-integration test. This relationship could be written as following equation;

$$
\sqrt{\frac{N_{N, T}^{\prime}-\mu \sqrt{N}}{\sqrt{V}}} \rightarrow N(0,1)
$$

In equation 9, $\mu$ and $V$ stand for the Monte Carlo oriented adjustment measures.

The first four results of Panels (v, rho, PP, and ADF statistics) in the Table 9 are withindimension statistics and latter three Groups (rho, PP and ADF) are between the dimension statistics. Therefore, we have at least 4 statistics out of 7 fulfills the lowest criterion for long-run linear co-integration approval within target variables.

After the approval of cross dependence between the target variables, the co-integration test by Westerlund (2007) has the ability to produce stable and vigorous results for the approval of the co-integration level. The results of (Westerlund 2007) are present in the form of two groups/forms. The first group is called cluster based group (Gt and Ga), whereas, other group is 
called panel statistics group (Pt and pa) (Rauf et al. 2018a, Saud et al. 2019) as shown in Table 8. The results show that co-integration exists among $\mathrm{CO}_{2}$ and all other independent variables for all the 49 countries of the study regions.

\subsubsection{The Dynamic Panel Data Estimation}

The FMOLS valuation proposed by Pedroni(Pedroni 2001) and the DOLS valuation proposed by (Kao \&Chiang 2001) and (Stock \&Watson 1993) that have been used in this recent study to explore the long-run co-integration amongst variables.

Meanwhile, the following FMOLS and DOLS equations are presented to test the hypotheses:

$\widehat{\beta}_{\mathrm{NT}}=\left[\frac{\sum_{\mathrm{i}=1}^{\mathrm{N}} \sum_{\mathrm{t}=1}^{\mathrm{T}}\left(\mathrm{x}_{\mathrm{it}}-\overline{\mathrm{x}}_{\mathrm{i}}\right)\left(\mathrm{y}_{\mathrm{it}}-\overline{\mathrm{y}}_{\mathrm{i}}\right)-\mathrm{T} \widehat{\mathrm{\gamma}}_{\mathrm{i}}}{\sum_{\mathrm{t}=1}^{\mathrm{T}}\left(\mathrm{x}_{\mathrm{it}}-\widehat{\mathrm{x}}_{\mathrm{i}}\right)^{2}}\right]$

Where $\quad \hat{\gamma}_{\mathrm{i}}=\hat{\Gamma}_{21 \mathrm{i}}+\widehat{\Omega}_{21 \mathrm{i}}^{0}-\frac{\widehat{\Omega}_{21 \mathrm{i}}}{\widehat{\Omega}_{21 \mathrm{i}}}\left(\hat{\Gamma}_{22 \mathrm{i}}+\widehat{\Omega}_{22 \mathrm{i}}^{2}\right)$

And $\quad \widehat{\Omega}_{\mathrm{i}}=\widehat{\Omega}_{\mathrm{i}}^{0}+\widehat{\Gamma}_{\mathrm{i}}+\hat{\Gamma}_{\mathrm{i}}^{\prime}$

Whereas, $\widehat{\Omega}_{i}=$ long-run matrix of stationarity, $\widehat{\Omega}_{21 i}^{0}=$ term to reject the covariance b/w errors terms of stationarity, and $\widehat{\Gamma}_{i}=$ modified covariance between independent variables.

\subsubsection{Heterogeneous Panel Causality test}

At the last stage of econometric analysis, the panel Granger causality test has been used to find the instrumental correlation between target variables under investigation in the study.

\section{Results and Discussions}


The present study used a series of correlational and cross-sectional dependence tests to develop understanding about the effects of energy growth, financial development, GDP, medium and high-tech industries, trade openness and renewable energy consumption on the emissions of Carbon Dioxide $\left(\mathrm{CO}_{2}\right)$. The results presented in the form of series of Tables to clearly represent the outcomes of the present study for the regions and countries of the study. The empirical results obtained through current investigation can help the policy makers to achieve "Green BRI" goals in regional panels.

\subsection{Descriptive Statistics}

The summary of statistics has been presented in Table 4 comprising 49 countries and 1274 observations dataset. The variables data has been standardized by using natural logarithm to avoid heteroscedasticity. The consumption of energy was a trending variable with the mean of 1945.1240 and a standard deviation of 2698.9130. The mean emissions of $\mathrm{CO}_{2}$ were lower (5.0492) in million tons but it was highly variable in the different countries of the different regions. This type of variation indicates the different level of advancement in individual countries. Similarly, mean GDP of the overall countries in the panel was higher (2698.9130) with lower standard deviation indicating the improved state of economy of the countries of the regions under investigation. The mean value of FD and MHI had similar outcomes (38.2041 and 24.4740 respectively) indicating their strong dependence on each other. Similarly, TOP and FDI shows similar trends in the given time span.

Table 4. Descriptive Statistics

\begin{tabular}{lllllllll} 
Variable $\rightarrow$ & $\mathbf{C O}_{2}$ & EC & FD & FDI & GDP & MHI & REC & TOP \\
\hline Mean & 5.0492 & 1945.1240 & 38.2041 & 4.0261 & 2698.9130 & 24.4740 & 17.6670 & 88.0877
\end{tabular}




\begin{tabular}{lllllllll}
\hline Median & 2.9844 & 899.8239 & 33.4432 & 2.7452 & 4456.3600 & 24.0068 & 6.0378 & 81.1580 \\
\hline Maximum & 35.9158 & 12406.7500 & 165.3904 & 54.2391 & 64864.7200 & 88.0370 & 92.3802 & 437.3267 \\
\hline Minimum & 0.0000 & 0.0000 & 0.0000 & -40.4143 & 0.0000 & 0.0000 & 0.0000 & 0.0000 \\
\hline Std. Dev. & 6.4352 & 2698.9130 & 34.1423 & 5.5015 & 11334.0600 & 17.0908 & 23.1835 & 58.3168 \\
\hline Skewness & 2.1786 & 2.2411 & 1.0170 & 2.3774 & 2.4375 & 0.6725 & 1.4498 & 2.0877 \\
\hline Kurtosis & 7.9716 & 7.7552 & 3.8979 & 26.4151 & 9.4368 & 3.6670 & 4.2063 & 11.1954 \\
\hline Jarque-Bera & 2319.8320 & 2266.6950 & 262.4066 & 30303.8600 & 3460.9280 & 119.6407 & 523.5765 & 4490.7950 \\
\hline Probability & 0.0000 & 0.0000 & 0.0000 & 0.0000 & 0.0000 & 0.0000 & 0.0000 & 0.0000 \\
\hline Sum & 6432.74 & 2478088 & 48672.04 & 5129.211 & 11037057 & 31179.84 & 22507.74 & 112223.7 \\
\hline Observations & 1274 & 1274 & 1274 & 1274 & 1274 & 1274 & 1274 & 1274 \\
\hline
\end{tabular}

299

300

301

302

303

304

305

306

307

308

309

310

311

312

\subsection{Correlation Analyses}

The present study correlation analyses results show the highly significant positive correlation between $\mathrm{CO}_{2}$ and $\operatorname{GDP}(0.7153 * * *)$ MHI $(0.2564 * *)$, EC $\left(0.8063^{* * *}\right)$, FD $(0.08291 * * *)$ and TOP $\left(0.2080^{* * *}\right)$ respectively. There was highly significant negative correlation found between $\mathrm{CO}_{2}$ and $\operatorname{REC}\left(-0.3956^{* * *}\right)$ and as shown in Table 5. There was no significant correlation found between $\mathrm{CO}_{2}$ and financial development (FDI). The results of strong association between GDP, MHI, and EC and $\mathrm{CO}_{2}$ has also been observed by Rauf et al. (2020). But current study result contradicts the weak correlation results of $\mathrm{CO}_{2}$ and FD with (Rauf et al. 2020). Therefore, it can be easily observed that $\mathrm{CO}_{2}$ emissions are mainly connected with the GDP of the countries, medium and high-tech industries, and energy consumption as correlation statistics indicated clearly about it. These indicators are main drivers of the atmospheric $\mathrm{CO}_{2}$ emissions and controls the atmospheric conditions through increased greenhouse gas emissions in the countries under current investigation. Therefore, the two-way 


\begin{tabular}{|c|c|c|c|c|c|c|c|c|}
\hline $\begin{array}{l}\text { Variab } \\
\text { le }\end{array}$ & $\mathrm{CO}_{2}$ & EC & FD & FDI & GDP & MHI & REC & TOP \\
\hline $\mathrm{CO}_{2}$ & 1.0000 & & & & & & & \\
\hline $\mathrm{EC}$ & $\begin{array}{l}0.8063 * * \\
*\end{array}$ & 1.0000 & & & & & & \\
\hline FD & $\begin{array}{l}0.08291 * \\
* *\end{array}$ & $0.0577 * *$ & 1.0000 & & & & & \\
\hline FDI & 0.02907 & $\begin{array}{l}0.0815 * * \\
*\end{array}$ & $\begin{array}{l}0.1795 * * \\
*\end{array}$ & 1.0000 & & & & \\
\hline GDP & $\begin{array}{l}0.7153 * * \\
*\end{array}$ & $\begin{array}{l}0.5745 * * \\
*\end{array}$ & $\begin{array}{l}0.2331 * * \\
*\end{array}$ & $\begin{array}{l}0.1343 * * \\
*\end{array}$ & 1.0000 & & & \\
\hline MHI & $\begin{array}{l}0.2564 * * \\
*\end{array}$ & $\begin{array}{l}0.2280 * * \\
*\end{array}$ & $0.3897 * *$ & $0.0835^{* *}$ & $\begin{array}{l}0.4267 * * \\
*\end{array}$ & 1.0000 & & \\
\hline REC & $\begin{array}{l}- \\
0.3956 * * \\
*\end{array}$ & $\begin{array}{l}- \\
0.3394 * * \\
*\end{array}$ & $\begin{array}{l}- \\
0.2230 * * \\
*\end{array}$ & $\begin{array}{l}- \\
0.1180 * * \\
*\end{array}$ & $\begin{array}{l}- \\
0.3904 * * \\
*\end{array}$ & $\begin{array}{l}- \\
0.2234 * * \\
*\end{array}$ & 1.0000 & \\
\hline TOP & $\begin{array}{l}0.2080 * * \\
*\end{array}$ & $\begin{array}{l}0.2283 * * \\
*\end{array}$ & $\begin{array}{l}0.3752 * * \\
*\end{array}$ & $0.4265 * *$ & $\begin{array}{l}0.4050 \\
* * *\end{array}$ & $\begin{array}{l}0.4427 * * \\
*\end{array}$ & $\begin{array}{l}- \\
0.2271 * * \\
*\end{array}$ & $\begin{array}{l}1.000 \\
0\end{array}$ \\
\hline
\end{tabular}

$1 *, * *, * * *$ shows statistical significance at the $10 \%, 5 \%$ and $1 \%$ respectively.

correlation estimated provides a good insight into series of datasets. However, it is important to further validate the results and develop cross sectional relationships to cross validate the established preposition.

Table 5. Correlation Statistics

\subsubsection{Unit Root tests and Slope Homogeinity}

This study used first-generation/type LLC, IPS and ADF (Table 6) and secondgeneration/type CIPS and CADF (Table 7) of unit root tests for data stationarity checking. The stationarity of individual variables examined and results indicated the difference between 
variables in panels of study regions. Some of the unit roots tests discarded the null hypothesis at their level, the stationarity at $1^{\text {st }}$ order has been supported by most of the tests. The results of CD test showed strong cross dependence between variables. Further, study examined the slope heterogeneity test for heterogenous panels in Table 8 . The Pedroni and Kao based tests $\left(1^{\text {st }}\right.$ type /generation co-integration tests) might face the issue of lower co-integration between the variables. To avoid this problem with Pedroni and Kao based co-integration tests, the (Westerlund 2007) has been used to estimate the level of co-integration between study variables, (see (Yasmeen et al. 2018). The Pedroni co-integration test gave strong evidence of rejecting null hypothesis through 4 out of 7 values having higher significance level "p". The results of Westerlund co-integration test under the cross-dependence situation proved to be the best choice as shown in Table 9 which validates the long-run co-integration between variables. The results of Pedroni (Table 10) and Kao (Table 11) shows the high level of co-integration among all variables in long-run. Further investigations using FMOLS and DOLS models will give insight into the long-run co-integration in full and regional panels.

Table 6. Panel Unit Root test results (LLC, IPS and ADF)

\begin{tabular}{|c|c|c|c|c|c|c|c|c|}
\hline \multicolumn{9}{|l|}{ At level } \\
\hline Methods & $\mathrm{CO}_{2}$ & EC & FD & FDI & GDP & MHI & REC & TOP \\
\hline $\begin{array}{l}\text { Levin, Lin \& } \\
\text { Chu t* }\end{array}$ & $\begin{array}{l}6.2575 \\
8\end{array}$ & $\begin{array}{l}9.0830 \\
5\end{array}$ & $\begin{array}{l}0.3153 \\
7\end{array}$ & $\begin{array}{l}- \\
7.1973 \\
5 * * *\end{array}$ & $\begin{array}{l}2.7861 \\
7\end{array}$ & $\begin{array}{l}31.398 \\
2\end{array}$ & $\begin{array}{l}4.9201 \\
6\end{array}$ & $\begin{array}{l}- \\
20.249 \\
6 * * *\end{array}$ \\
\hline $\begin{array}{l}\text { Im, Pesaran } \\
\text { and Shin }\end{array}$ & $\begin{array}{l}6.1258 \\
3\end{array}$ & $\begin{array}{l}7.9944 \\
0\end{array}$ & $\begin{array}{l}1.9067 \\
7\end{array}$ & $\begin{array}{l}- \\
8.4359 \\
6 * * *\end{array}$ & $\begin{array}{l}5.7933 \\
8\end{array}$ & $\begin{array}{l}5.9824 \\
4\end{array}$ & $\begin{array}{l}6.2350 \\
7\end{array}$ & $\begin{array}{l}- \\
13.017 \\
0 * * *\end{array}$ \\
\hline $\begin{array}{l}\text { ADF - Fisher } \\
\text { Chi-square }\end{array}$ & $\begin{array}{l}45.207 \\
5\end{array}$ & $\begin{array}{l}13.920 \\
1\end{array}$ & $\begin{array}{l}75.935 \\
2\end{array}$ & $\begin{array}{l}256.12 \\
5 * * *\end{array}$ & $\begin{array}{l}65.704 \\
6\end{array}$ & $\begin{array}{l}48.270 \\
1\end{array}$ & $\begin{array}{l}51.045 \\
6\end{array}$ & $\begin{array}{l}174.24 \\
9 * * *\end{array}$ \\
\hline
\end{tabular}




\section{At first Difference}

\begin{tabular}{|c|c|c|c|c|c|c|c|c|}
\hline Methods & $\mathrm{CO}_{2}$ & $\overline{E C}$ & FD & FDI & GDP & MHI & REC & TOP \\
\hline $\begin{array}{l}\text { Levin, Lin \& } \\
\text { Chu t* }\end{array}$ & $\begin{array}{l}- \\
16.771 \\
6 * * *\end{array}$ & $\begin{array}{l}- \\
18.418 \\
0 * * *\end{array}$ & $\begin{array}{l}- \\
4.3673 \\
5 * * *\end{array}$ & $\begin{array}{l}- \\
16.701 \\
8 * * *\end{array}$ & $\begin{array}{l}- \\
301.09 \\
0 * * *\end{array}$ & $\begin{array}{l}186.93 \\
6\end{array}$ & $\begin{array}{l}- \\
28.892 \\
3 * * *\end{array}$ & $\begin{array}{l}- \\
117.81 \\
7 * * *\end{array}$ \\
\hline $\begin{array}{l}\text { Im, Pesaran } \\
\text { and Shin }\end{array}$ & $\begin{array}{l}- \\
14.256 \\
9 * * *\end{array}$ & $\begin{array}{l}- \\
13.997 \\
8 * * *\end{array}$ & $\begin{array}{l}- \\
12.679 \\
0 * * *\end{array}$ & $\begin{array}{l}- \\
21.985 \\
1 * * *\end{array}$ & $\begin{array}{l}- \\
80.347 \\
1 * * *\end{array}$ & $\begin{array}{l}0.8861 \\
1\end{array}$ & $\begin{array}{l}- \\
24.521 \\
3 * * *\end{array}$ & $\begin{array}{l}- \\
54.980 \\
0 * * *\end{array}$ \\
\hline $\begin{array}{l}\text { ADF - Fisher } \\
\text { Chi-square }\end{array}$ & $\begin{array}{l}383.61 \\
9 * * *\end{array}$ & $\begin{array}{l}374.26 \\
5 * * *\end{array}$ & $\begin{array}{l}362.66 \\
6 * * *\end{array}$ & $\begin{array}{l}614.25 \\
8 * * *\end{array}$ & $\begin{array}{l}395.85 \\
7 * * *\end{array}$ & $\begin{array}{l}136.90 \\
9 * * *\end{array}$ & $\begin{array}{l}651.30 \\
0 * * *\end{array}$ & $\begin{array}{l}751.82 \\
1 * * *\end{array}$ \\
\hline
\end{tabular}

$1 *, * *, * * *$ shows statistical significance at the $10 \%, 5 \%$ and $1 \%$ respectively.

Table 7. Results of CIPS and CADF (Panel unit root tests)

\begin{tabular}{|c|c|c|c|c|c|c|c|c|}
\hline \multicolumn{9}{|c|}{ At Level } \\
\hline $\begin{array}{l}\text { Metho } \\
\text { ds }\end{array}$ & $\mathrm{CO}_{2}$ & EC & FD & FDI & GDP & MHI & REC & TOP \\
\hline CIPS & $2.679 * *$ & $\begin{array}{l}- \\
6.093 * * \\
*\end{array}$ & -2.169 & $\begin{array}{l}- \\
3.825 * * \\
*\end{array}$ & $\begin{array}{l}- \\
3.049 * * \\
*\end{array}$ & -2.202 & $-\overline{2.696 * *}$ & -2.401 \\
\hline CADF & -2.256 & -1.633 & $\begin{array}{l}- \\
3.033 * *\end{array}$ & $\begin{array}{l}- \\
3.131 * *\end{array}$ & $\begin{array}{l}- \\
2.539 * *\end{array}$ & -2.179 & -1.929 & -1.923 \\
\hline \multicolumn{9}{|c|}{ 1st Deference } \\
\hline Metho & $\mathrm{CO}_{2}$ & EC & FD & FDI & GDP & MHI & REC & TOP \\
\hline CIPS & $\begin{array}{l}- \\
\text { 2.679** } \\
*\end{array}$ & $\begin{array}{l}- \\
6.320 * * \\
*\end{array}$ & $\begin{array}{l}- \\
4.939 * * \\
*\end{array}$ & $\begin{array}{l}- \\
5.793 * * \\
*\end{array}$ & $\begin{array}{l}- \\
4.616 * * \\
*\end{array}$ & $\begin{array}{l}- \\
4.459 * * \\
*\end{array}$ & $\begin{array}{l}- \\
4.732 * * \\
*\end{array}$ & $\begin{array}{l}- \\
4.419 * * \\
*\end{array}$ \\
\hline CADF & $\begin{array}{l}- \\
3.896 * * \\
*\end{array}$ & $\begin{array}{l}- \\
3.638 * * \\
*\end{array}$ & $\begin{array}{l}- \\
3.491 * * \\
*\end{array}$ & $\begin{array}{l}- \\
4.580 * * \\
*\end{array}$ & $\begin{array}{l}- \\
3.411 * * \\
*\end{array}$ & $\begin{array}{l}- \\
3.352 * * \\
*\end{array}$ & $\begin{array}{l}- \\
3.168 * *\end{array}$ & $\begin{array}{l}- \\
3.373 * * \\
*\end{array}$ \\
\hline
\end{tabular}


Table 8. Testing for slope heterogeneity

\begin{tabular}{|c|c|c|}
\hline & Delta & P-value \\
\hline & $17.394 * * *$ & 0.000 \\
\hline Adj. & $21.512 * * *$ & 0.000 \\
\hline
\end{tabular}

Table 9. Westerlund test of Cointegration

\begin{tabular}{llll}
\hline$\underline{\text { Statistic }}$ & Value & $\underline{\text { Z-value }}$ & P-value \\
\hline $\mathrm{Gt}$ & $-13.126^{* * * *}$ & -49.216 & 0.0000 \\
\hline $\mathrm{Ga}$ & $-19.064^{*}$ & 11.516 & 0.058 \\
\hline $\mathrm{Pt}$ & $-56.338^{* * *}$ & -4.123 & 0.0000 \\
\hline $\mathrm{Pa}$ & $-24.097 * * *$ & 8.456 & 0.0000
\end{tabular}

$1 *, * *, * * *$ shows statistical significance at the $10 \%, 5 \%$ and $1 \%$ respectively.

Table 10. Pedroni test of Cointegration

\section{Weighted}

\begin{tabular}{lllll}
\hline Panel and Group statistics & Statistic & Probability & Statistic & Probability. \\
\hline v-Statistic (Panel) & $2.5574 * * *$ & 0.0053 & -0.0548 & 0.5219 \\
\hline rho-Statistic (Panel) & 1.8471 & 0.9676 & 1.2252 & 0.8898 \\
\hline PP-Statistic (Panel) & $-2.7401 * * *$ & 0.0031 & $-5.6625 * * *$ & 0.0000 \\
\hline ADF-Statistic (Panel) & $-7.7309 * * *$ & 0.0000 & $-8.2642^{* * *}$ & 0.0000 \\
\hline rho-Statistic (Group) & $4.2118^{* * *}$ & 1.0000 & & \\
\hline PP-Statistic (Group) & $-5.3655^{* * *}$ & 0.0000 & \\
\hline ADF-Statistic (Group) & $-7.7040^{* * *}$ & 0.0000 & \\
\hline 1 *** shows statistical significance at $1 \%$ significance level. & & \\
\hline
\end{tabular}


The Kao co-integration test employed to validate the results of Pedroni co-integration tests. The result of Kao test showed $-13.18381 * * *$ (Table 11), which clearly indicates that the previously applied integration tests were efficient and Kao test results are authenticating those previously obtained outcomes of co-integration. The similar results found in the study by (Rauf et al. 2018b) where their results of Pedroni co-integration tests were validated by Kao co-integration test.

Table 11. Kao test of Cointegration

\begin{tabular}{lcc}
\hline & $\underline{\text { t-Statistic }}$ & Prob. \\
\hline ADF & $-13.18381^{* * *}$ & 0.0000 \\
\hline Residual variance & 0.126030 & \\
\hline HAC variance & 0.111819 & \\
\hline $1 * * *$ shows statistical significance at $1 \%$ significance level.
\end{tabular}

\subsubsection{Dynamic Panel data models}

The estimations obtained from co-integration test validated the long term relationship among variables which gave strong reason to apply FMOLS and DOLS to get stable outcomes(Pedroni 2001); (Pedroni 2004). Both DOLS and FMOLS has been used to establish the expected relationship between the regressor and the regressed. The results shown in Table 12 clearly reveals that EC, FDI, GDP, and MHI found unfavorably influencing the environmental quality through carbon dioxide emissions. These results can be validated by results obtained from (Rauf et al. 2020). Renewable energy consumption (REC), and trade openness (TOP) have favorable effect on the environment. (Rauf et al. 2018b) also found that trade openness do not have negative effects on the environment in BRI partner countries. 
Table 12. Results for FMOLS and DOLS for countries undder investigation

\section{Regressor: $\mathrm{CO}_{2}$ Emissions}

\section{Panel-49 BRI countries}

\begin{tabular}{l|l|l}
\hline Variables & Coefficients & DOLS \\
\hline LNEC & FMOLS & $0.282734 * * *$ \\
\hline LNFD & $0.173604 * * *$ & 0.031297 \\
\hline LNFDI & 0.000992 & 0.054350 \\
\hline LNGDP & $0.044221 * *$ & $0.467377 * * *$ \\
\hline LNMHI & $0.438718 * * *$ & -0.155954 \\
\hline LNREC & $0.170090 * * *$ & $-0.482432 * * *$ \\
\hline LNTOP & $-0.306305 * * *$ & 0.015257 \\
\hline R-squared & -0.002527 & 0.999602 \\
\hline Adjusted R-squared & 0.869660 & 0.989165 \\
\hline
\end{tabular}

Precisely, it can be observed from the results of FMOLS that $1 \%$ increase in energy consumption EC, FDI, GDP and MHI leads to the degradation of environment $\left(\mathrm{CO}_{2}\right.$ emissions)

$0.170090 * * *$ respectively. The results of both models (DOLS and FMOLS) found to have been similar in terms of developing relationship between regressor and the regressed ones. We can summarize from the results of both models that the 49 countries studied need to understand that economic growth, medium and high-tech industries and foreign direct investments should transform their sources of energy generation from fossil fuel based to renewable energy 
countries is dependent on the consumption of energy. The increased magnitude of the energy consumption will cause the increased impact on the environment. It further leads the researchers to emphasis mainly on the innovation-based advancements. The adaptation of energy efficient technologies can reduce the burden on energy generation sector (Choi et al. 2012), which will ultimately have reduced impact on the ecological health of the countries. Therefore, it is strongly recommended to promote renewable energy generation and sharing of environment friendly technologies among the BRI partner countries for sustainable economic growth with minimum impact on the ecological health of the partner countries. In this regard, the Green BRI initiative is the good step to promote the environment friendly technologies and options for sustainable energy, economy and environmental growth in BRI partner countries. The current study results infers similar outcomes to (Apergis \&Ozturk 2015, Arouri et al. 2012, Atici 2009, Bekhet \&Othman 2017, Hafeez et al. 2018, Jalil \&Mahmud 2009, Khan et al. 2017, Nasir \&Rehman 2011, Omri 2013, Rauf et al. 2018b, Xu \&Lin 2016b). The option of carbon free technologies such as nuclear, biomass based, wind turbines, hydropower, and solar energy and their associated technologies can transform the growth patterns of BRI partner countries with improved environmental quality. (Javid \&Sharif 2016) found similar findings for Pakistan, (Zhang \&Gao 2016) and (Xu \&Lin 2016b) for China, (Kasman \&Duman 2015) for European Union members, ((Rauf et al. 2018a); (Rauf et al. 2020); (Rauf et al. 2018b) for BRI member countries.

\subsubsection{The Panel granger causality analysis}

The causality between $\mathrm{CO}_{2}$ and independent variables has been investigated using Granger panel causality analysis. (Dumitrescu \&Hurlin 2012) developed the causality test, which also addresses the problem of heterogeneity among variables. Therefore, the causality test by (Dumitrescu \&Hurlin 2012) has been used in the present study for the selected BRI countries. The divergent 


\begin{tabular}{|c|c|c|c|c|c|}
\hline Null Hypothesis: & Zbar-Stat. & Prob. & \multicolumn{3}{|c|}{ Relationship directions } \\
\hline$L N E C \neq \mathrm{LNCO}_{2}$ & $46.9575 * * *$ & 0.0000 & \multirow{2}{*}{$L N E C$} & \multirow{2}{*}{$\rightarrow$} & \multirow{2}{*}{$\mathrm{LNCO}_{2}$} \\
\hline $\mathrm{LNCO}_{2} \neq$ & 0.56576 & 0.5716 & & & \\
\hline LNFD $\quad \neq \quad \mathrm{LNCO}_{2}$ & $40.5894 * * *$ & 0.0000 & \multirow{2}{*}{$L N F D$} & \multirow{2}{*}{$\leftrightarrow$} & \multirow{2}{*}{$\mathrm{LNCO}_{2}$} \\
\hline $\mathrm{LNCO}_{2} \neq \mathrm{LNFD}$ & $21.5626 * * *$ & 0.0000 & & & \\
\hline LNFDI $\neq \mathrm{LNCO}_{2}$ & -0.44992 & 0.6528 & \multirow{2}{*}{$L N F D I$} & \multirow{2}{*}{$\leftarrow$} & \multirow{2}{*}{$\mathrm{LNCO}_{2}$} \\
\hline $\mathrm{LNCO}_{2} \neq \mathrm{LNFDI}$ & $4.27438 * * *$ & 0.0000 & & & \\
\hline$L N G D P \neq L^{2 N C O}$ & $2.21961 * *$ & 0.0264 & \multirow{2}{*}{$L N G D P$} & \multirow{2}{*}{$\leftrightarrow$} & \multirow{2}{*}{$\mathrm{LNCO}_{2}$} \\
\hline $\mathrm{LNCO}_{2} \neq L N G D P$ & $8.40507 * * *$ & 0.0000 & & & \\
\hline$L N M H I \neq L^{2 N C O}$ & $-2.6427 * * *$ & 0.0082 & \multirow{2}{*}{$L N M H I$} & \multirow{2}{*}{$\leftrightarrow$} & \multirow{2}{*}{$\mathrm{LNCO}_{2}$} \\
\hline $\mathrm{LNCO}_{2} \neq \mathrm{LNMHI}$ & $181.943 * * *$ & 0.0000 & & & \\
\hline$L N T O P \neq \quad L^{2 N C O}$ & 1.28659 & 0.1982 & \multirow{2}{*}{$L N T O P G$} & \multirow{2}{*}{$\leftarrow$} & \multirow{2}{*}{$\mathrm{LNCO}_{2}$} \\
\hline $\mathrm{LNCO}_{2} \neq \mathrm{LNTOP}$ & $23.939 * * *$ & 0.0000 & & & \\
\hline$L N R E C \neq \mathrm{LNCO}_{2}$ & $80.8119 * * *$ & 0.0000 & \multirow{2}{*}{ LNREC } & \multirow{2}{*}{$\leftrightarrow$} & \multirow{2}{*}{$\mathrm{LNCO}_{2}$} \\
\hline $\mathrm{LNCO}_{2} \neq \mathrm{LNREC}$ & $2.2346^{* *}$ & 0.0254 & & & \\
\hline
\end{tabular}
Granger causality test are presented in Table 12. The results are showing quite clear causal relationship of $\mathrm{CO}_{2}$ with other variables. Energy consumption has unidirectional (one way) relationship with $\mathrm{CO}_{2}$ emissions, while financial development, GDP, MHI and REC showed bidirectional (feedback type) relationship with $\mathrm{CO}_{2}$. Foreign direct investment (FDI), and TOP has inverse unidirectional relationship with $\mathrm{CO}_{2}$. The resultant pathways of relationship of independent variable with environmental health will help the policymakers to let them develop sustainable and environment friendly strategies in BRI partner countries.

Table 13. Dumitrescu Hurlin Panel Causality analysis

results of causality test found for the 49 BRI partner countries in the present study. The results of 
This causal relationship between target variables clearly justifies the high rate of $\mathrm{CO}_{2}$ emissions connectedness with the economic advancement (Table 13). It conclusively defines the influence of economic growth on the environmental health in the BRI partner countries. Carrying on these kind of economic development activities may lead to the increased global warming along with unprecedented type of human health effects. The possible solution of such negative thrust back of economic growth is the adaption of technologically advanced and green solutions. These type of causal relationships are also found in studies by (Al-Mulali et al. 2015, Katircioglu 2017); (Rauf et al. 2020, Saud et al. 2019)).

\subsection{Checking regression robustness}

The results of DOLS and FMOLS presented to see robustness (Table 11), this study applies the Dynamic Seemingly Unrelated Regression (DSUR). The purpose of applying DSUR is to check the robustness in the oucomes obtained from FMOLS and DOLS tests. The results presented in Table 14 shows that there was medium to high impact of indicators under investigation on emissions of Carbon dioxide $\left(\mathrm{R}^{2}=0.60\right)$ in the countries under investigation in the present study.

Table 14. Dynamic seemingly unrelated regression results

\begin{tabular}{|c|c|c|c|c|}
\hline Panel & Variable & Coefficient & $\underline{\text { z-Statistic }}$ & Prob. \\
\hline & LNEC & $0.1559787 * * *$ & 24.67 & 0.0000 \\
\hline & LNFD & $-0.0285969 * *$ & -2.51 & 0.0120 \\
\hline & LNFDI & $0.0584332 * * *$ & 3.96 & 0.0000 \\
\hline & LNGDP & $0.3897101 * * *$ & 21.37 & 0.0000 \\
\hline $49 \mathrm{BRI}$ countries & LNMHI & $0.1741924 * * *$ & 9.93 & 0.0000 \\
\hline
\end{tabular}




\begin{tabular}{llll} 
LNREC & $-0.243571 * * *$ & -21.03 & 0.0000 \\
\hline LNTOP & $0.0600654 * * *$ & 3.76 & 0.0000 \\
\hline CONSTANT & $-3.481891 * * *$ & -23.78 & 0.0000 \\
\hline R-squared & 0.7559 & & \\
\hline Chi Square & $3944.86 * * *$ & &
\end{tabular}

423

The results of DSUR endorse the results obtained by using FMOLS and DOLS, where EC, FDI, GDP and MHI are major drivers of the environmental degradation (Table 14). Trade openness and renewable energy consumption favored the environment as also found in FMOLS and DOLS test results. The indicator of FD has not been found with significant relationship with the emissions of $\mathrm{CO}_{2}$, having similar results as previously used both models.

\section{Conclusions}

The present study conducted to examine the impacts of energy consumption, GDP, financial development, renewable energy consumption, foreign direct investment, and medium and high-tech industry on the emissions of Carbon dioxide $\left(\mathrm{CO}_{2}\right)$ in 49 nations on the panel of Belt and Road initiative. The duration of investigation expands from 1994 to 2019. The robust type of panel cross-section dependence and slope heterogeneity and other methods were adopted to analyze the dataset of BRI countries under investigation. The standardized (log-transformed) data has been used to employ slope heterogeneity, cross-sectional dependency of the panel data to confirm that the estimate drawn from the dataset is reliable.

Afterwards, panel tests (co-integration tests) used to verify the long-term integrated forms amongst the variables and, FMOLS and DOLS models used for long-term equilibrium relationship among the variables. Finally, The Panel Heterogeneous Granger causality test 
applied to detect the interconnectivity between variables at causal bases (mainly $\mathrm{CO}_{2}$ emissions with other independent variables). The consumption of energy (EC) along with foreign direct investment (FDI), medium and high-tech industry (MHI) and GDP has been found highly unfavorable for the ecological health $\left(\mathrm{CO}_{2}\right.$ emissions) in 49 nations on BRI panel. However, renewable energy consumption (REC) has been found a favorable impact on the environment quality parameter $\left(\mathrm{CO}_{2}\right)$. There was no significant impact of financial development (FD) indicator on $\mathrm{CO}_{2}$ emissions has been observed in the present study.

More precisely, the energy consumption, medium and high-tech industries and GDP has been the major variables found in all analytical outcomes, those having highly significant impacts on the environmental quality/health $\left(\mathrm{CO}_{2}\right.$ emissions). However, the adaptation of renewable energy sources has been found in significantly obliging impacts (favorable) in all analytical outcomes with ecological health of the countries in BRI panel. The present outcomes clearly claim the strong relationship of economic growth with increased $\mathrm{CO}_{2}$ emissions in all 49 nations under investigation of Belt and Road initiative.

Therefore, it can be concluded that the huge investments of Chinese government under BRI projects on energy sector (mainly based on fossil fuel-based energy generation) along with industrial sector development are driving factors behind the environmental deterioration in those countries. However, the impacts of BRI projects on environment can be minimized using renewable energy generation sources especially those of carbon free energy generation technologies. Further, the industrial pollution can also be minimized through regulating them according to the environmental standards. The governments of BRI listed countries can formulate sustainable options of green energy, green transport, green innovation and green standards, which are in line with the initiative taken by Ministry of Ecology and Environment of 
China. Present study can provide a strong justification of sustainable economic growth for the policy makers of BRI partner countries while keeping in mind the environmental implications. The transfer of technology between the partner countries can also help to transform the economic growth into an energy efficient and sustainable development.

The estimates of recent study suggest some essential policy implications for lawmakers and environmental experts. They must allocate economic resources based on the results of the study to maximize productivity, but wisely. As a result, researchers will take short- and longterm approaches to environmental issues, in particular the involvement of greenhouse gases (GHGs) and the BRI economy's climate change sensitivity. This shows that continued economic expansion is the key to improving the quality of the environment. Thus, for all regions tested to reduce $\mathrm{CO}_{2}$ emissions, more practical and stringent policies / strategies are needed from decision makers and stakeholders. In addition, the various estimates of the current study are a useful tool for developing renewable energy supply strategies to avoid the risk of (GHG) emissions not only for the BRI partnered nations but it will be great gadget for larger countries of the world. It is also important to anticipate demand and supply of energy to achieve the development of BRI projects. In addition, improved GDP per capita (income) will allow the general public with the provision of more dynamic and environment friendly services. Therefore, it is also important for policy makers to incentivize and appreciate investors for green investment and inform them about its benefits.

Additionally, researchers can modify variables that may produce points that can further help to improve the understanding about the impacts of BRI projects investments on Environment in general and on the regional climate in particular. In addition, we could measure the relationship of energy and economic growth indicators with many other climate change and 


\begin{tabular}{llll}
\hline S.No & Countries & S.No & Countries \\
\hline 1 & Albania & 26 & North Macedonia \\
\hline 2 & Armenia & 27 & Mongolia \\
\hline 3 & Azerbaijan & 28 & Moldova \\
\hline 4 & Bahrain & 29 & Maldives \\
\hline 5 & Bangladesh & 30 & Malaysia \\
\hline 7 & Belarus & 31 & Myanmar \\
\hline 8 & Bosnia and Herzegovina & 32 & Nepal \\
\hline 9 & Bulgaria & 33 & Oman \\
\hline 10 & Colombodia & 34 & Pakistan \\
\hline 11 & Croatia & 35 & Philippines \\
\hline 12 & China & 36 & Romania \\
\hline 13 & Czech Republic & 37 & Russian Federation \\
\hline 14 & Egypt, Arab Rep. & 38 & Poland \\
\hline 15 & Georgia & 39 & Saudi Arabia \\
\hline 16 & Hungary & 40 & Singapore \\
\hline 17 & India & 41 & Slovak Republic \\
\hline 18 & Indonesia & Sri Lanka \\
\hline & & 42 & Thailand \\
\hline 6 & & \\
\hline
\end{tabular}

\section{Appendix A}

Table A1: List of Selected BRI countries

of sulfur, Carbon Monoxide, industrial pollution and health effects, in order to obtain an overall environmental impression. 


\begin{tabular}{llcl}
\hline 19 & Iran, Islamic Rep. & 44 & Turkey \\
\hline 20 & Israel & 45 & Tajikistan \\
\hline 21 & Jordan & 46 & Ukraine \\
\hline 22 & Kazakhstan & 47 & Yemen, Rep. \\
\hline 23 & Kyrgyz Republic & 48 & United Arab Emirates \\
\hline 24 & Kuwait & 49 & Vietnam \\
\hline 25 & Lebanon & & \\
\hline
\end{tabular}

492

493

494

495

496

497

498

499 
References

Al-Mulali U, Sab CNBC, Fereidouni HG (2012): Exploring the bi-directional long run relationship between urbanization, energy consumption, and carbon dioxide emission. Energy 46, 156-167

Al-Mulali U, Fereidouni HG, Lee JY, Sab CNBC (2013): Exploring the relationship between urbanization, energy consumption, and $\mathrm{CO} 2$ emission in MENA countries. Renewable and Sustainable Energy Reviews 23, 107-112

Al-Mulali U, Tang CF, Ozturk I (2015): Does financial development reduce environmental degradation? Evidence from a panel study of 129 countries. Environmental Science and Pollution Research 22, 14891-14900

Apergis N, Ozturk I (2015): Testing environmental Kuznets curve hypothesis in Asian countries. Ecological Indicators 52, 16-22

Arouri MEH, Youssef AB, M'henni H, Rault C (2012): Energy consumption, economic growth and $\mathrm{CO} 2$ emissions in Middle East and North African countries. Energy policy 45, 342349

Atici C (2009): Carbon emissions in Central and Eastern Europe: environmental Kuznets curve and implications for sustainable development. Sustainable Development 17, 155-160

Ayeche MB, Barhoumi M, Hammas M (2016): Causal linkage between economic growth, financial development, trade openness and $\mathrm{CO} 2$ emissions in European Countries. American Journal of Environmental Engineering 6, 110-122

Balsalobre-Lorente D, Shahbaz M, Roubaud D, Farhani S (2018): How economic growth, renewable electricity and natural resources contribute to $\mathrm{CO} 2$ emissions? Energy Policy $113,356-367$

Baltagi BH, Feng Q, Kao C (2012): A Lagrange Multiplier test for cross-sectional dependence in a fixed effects panel data model. Journal of Econometrics 170, 164-177

Behera SR, Dash DP (2017): The effect of urbanization, energy consumption, and foreign direct investment on the carbon dioxide emission in the SSEA (South and Southeast Asian) region. Renewable and Sustainable Energy Reviews 70, 96-106

Bekhet HA, Othman NS (2017): Impact of urbanization growth on Malaysia CO2 emissions: Evidence from the dynamic relationship. Journal of cleaner production 154, 374-388

Breusch TS, Pagan AR (1980): The Lagrange multiplier test and its applications to model specification in econometrics. The review of economic studies 47, 239-253

Cai X, Che X, Zhu B, Zhao J, Xie R (2018): Will developing countries become pollution havens for developed countries? An empirical investigation in the Belt and Road. Journal of Cleaner Production 198, 624-632

Chen H (2016): China's 'One Belt, One Road'initiative and its implications for Sino-African investment relations. Transnational Corporations Review 8, 178-182

Choi I (2006): Combination unit root tests for cross-sectionally correlated panels. Econometric Theory and Practice: Frontiers of Analysis and Applied Research: Essays in Honor of Peter CB Phillips. Cambridge University Press, Chapt 11, 311-333

Choi Y, Zhang N, Zhou P (2012): Efficiency and abatement costs of energy-related CO2 emissions in China: A slacks-based efficiency measure. Applied Energy 98, 198-208

Ciarreta A, Zarraga A (2010): Economic growth-electricity consumption causality in 12 European countries: A dynamic panel data approach. Energy policy 38, 3790-3796 
Doğan B, Driha OM, Balsalobre Lorente D, Shahzad U (2021): The mitigating effects of economic complexity and renewable energy on carbon emissions in developed countries. Sustainable Development 29, 1-12

Dombrowski K (2017): Clean at Home, Dirty Abroad

Du J, Zhang Y (2018): Does one belt one road initiative promote Chinese overseas direct investment? China Economic Review 47, 189-205

Dumitrescu E-I, Hurlin C (2012): Testing for Granger non-causality in heterogeneous panels. Economic modelling 29, 1450-1460

Economy W (2017): UNDP Says BRI Can Create Sustainable Growth. Financial Tribune

Fan J-L, Zhang Y-J, Wang B (2017): The impact of urbanization on residential energy consumption in China: An aggregated and disaggregated analysis. Renewable and Sustainable Energy Reviews 75, 220-233

Finance IIfG (2021): Green Belt and Road initiative center, Central University of Finance and Economics

Frees EW (1995): Assessing cross-sectional correlation in panel data. Journal of econometrics $69,393-414$

Frees EW (2004): Longitudinal and panel data: analysis and applications in the social sciences. Cambridge University Press

Friedman M (1937): The use of ranks to avoid the assumption of normality implicit in the analysis of variance. Journal of the american statistical association 32, 675-701

Grossman GM, Krueger AB (1995): Economic growth and the environment. The quarterly journal of economics 110, 353-377

Gulistan A, Tariq YB, Bashir MF (2020): Dynamic relationship among economic growth, energy, trade openness, tourism, and environmental degradation: fresh global evidence. Environmental Science and Pollution Research 27, 13477-13487

Hadri K (2000): Testing for stationarity in heterogeneous panel data. The Econometrics Journal $3,148-161$

Hafeez M, Chunhui Y, Strohmaier D, Ahmed M, Jie L (2018): Does finance affect environmental degradation: evidence from One Belt and One Road Initiative region? Environmental Science and Pollution Research 25, 9579-9592

Haseeb M, Azam M (2020): Dynamic nexus among tourism, corruption, democracy and environmental degradation: a panel data investigation. Environment, Development and Sustainability, 1-19

Ho D (2017): Cost of funding 'Belt and Road Initiative'is daunting task. South China Morning Post 27

Im KS, Pesaran MH, Shin Y (2003): Testing for unit roots in heterogeneous panels. Journal of econometrics 115, 53-74

Intelligence FB (2017): Available online: (accessed on 03 January, 2021) http://www.iberchina.org/files/2017/OBOR_Business_Implications_Fung.pdf

IPCC 2014: Intergovernmental Panel on Climate Change Fifth Assessment Report

Jalil A, Mahmud SF (2009): Environment Kuznets curve for CO2 emissions: a cointegration analysis for China. Energy policy 37, 5167-5172

Jaunky VC (2011): The CO2 emissions-income nexus: evidence from rich countries. Energy Policy 39, 1228-1240

Javid M, Sharif F (2016): Environmental Kuznets curve and financial development in Pakistan. Renewable and Sustainable Energy Reviews 54, 406-414 
Kao C, Chiang M-H (2001): On the estimation and inference of a cointegrated regression in panel data, Nonstationary panels, panel cointegration, and dynamic panels. Emerald Group Publishing Limited

Kasman A, Duman YS (2015): CO2 emissions, economic growth, energy consumption, trade and urbanization in new EU member and candidate countries: a panel data analysis. Economic modelling 44, 97-103

Katircioglu S (2017): Investigating the role of oil prices in the conventional EKC model: evidence from Turkey. Asian Economic and Financial Review 7, 498-508

Khan MK, Teng J-Z, Khan MI (2019): Effect of energy consumption and economic growth on carbon dioxide emissions in Pakistan with dynamic ARDL simulations approach. Environmental Science and Pollution Research 26, 23480-23490

Khan MK, Khan MI, Rehan M (2020): The relationship between energy consumption, economic growth and carbon dioxide emissions in Pakistan. Financial Innovation 6, 1-13

Khan MTI, Yaseen MR, Ali Q (2017): Dynamic relationship between financial development, energy consumption, trade and greenhouse gas: comparison of upper middle income countries from Asia, Europe, Africa and America. Journal of cleaner production 161, $567-580$

Kuznets S (1955): Economic growth and income inequality. The American economic review 45, 1-28

Levin A, Lin C-F, Chu C-SJ (2002): Unit root tests in panel data: asymptotic and finite-sample properties. Journal of econometrics 108, 1-24

Liu Y, Hao Y (2018): The dynamic links between CO2 emissions, energy consumption and economic development in the countries along "the Belt and Road". Science of the total Environment 645, 674-683

Musolesi A, Mazzanti M, Zoboli R (2010): A panel data heterogeneous Bayesian estimation of environmental Kuznets curves for CO2 emissions. Applied Economics 42, 2275-2287

Nasir M, Rehman FU (2011): Environmental Kuznets curve for carbon emissions in Pakistan: an empirical investigation. Energy policy 39, 1857-1864

Omri A (2013): CO2 emissions, energy consumption and economic growth nexus in MENA countries: Evidence from simultaneous equations models. Energy economics 40, 657-664

Pedroni P (1999): Critical values for cointegration tests in heterogeneous panels with multiple regressors. Oxford Bulletin of Economics and statistics 61, 653-670

Pedroni P (2001): Fully modified OLS for heterogeneous cointegrated panels, Nonstationary panels, panel cointegration, and dynamic panels. Emerald Group Publishing Limited

Pedroni P (2004): Panel cointegration: asymptotic and finite sample properties of pooled time series tests with an application to the PPP hypothesis. Econometric theory, 597-625

Pesaran MH (2004): General diagnostic tests for cross-sectional dependence in panels. Empirical Economics, $1-38$

Pesaran MH (2007): A simple panel unit root test in the presence of cross - section dependence. Journal of applied econometrics 22, 265-312

Petroleum B (2017): BP statistical review of world energy 2017. Br. Pet 66, 1-52

Rauf A, Liu X, Amin W, Ozturk I, Rehman OU, Hafeez M (2018a): Testing EKC hypothesis with energy and sustainable development challenges: a fresh evidence from belt and road initiative economies. Environmental Science and Pollution Research 25, 32066-32080 
Rauf A, Liu X, Amin W, Ozturk I, Rehman OU, Sarwar S (2018b): Energy and ecological sustainability: Challenges and panoramas in belt and road initiative countries. Sustainability 10, 2743

Rauf A, Liu X, Amin W, Rehman OU, Li J, Ahmad F, Bekun FV (2020): Does sustainable growth, energy consumption and environment challenges matter for Belt and Road Initiative feat? A novel empirical investigation. Journal of Cleaner Production 262, 121344

Saboori B, Sulaiman J (2013): $\mathrm{CO}_{2}$ emissions, energy consumption and economic growth in Association of Southeast Asian Nations (ASEAN) countries: a cointegration approach. Energy 55, 813-822

Saud S, Chen S, Haseeb A (2019): Impact of financial development and economic growth on environmental quality: an empirical analysis from Belt and Road Initiative (BRI) countries. Environmental Science and Pollution Research 26, 2253-2269

Schwerhoff G, Sy M (2017): Financing renewable energy in Africa-Key challenge of the sustainable development goals. Renewable and Sustainable Energy Reviews 75, 393-401

Stock JH, Watson MW (1993): A simple estimator of cointegrating vectors in higher order integrated systems. Econometrica: Journal of the Econometric Society, 783-820

Toman MT, Jemelkova B (2003): Energy and economic development: an assessment of the state of knowledge. The Energy Journal 24

Torney D, Gippner O (2018): China: deepening cooperation on climate and environmental governance, European Union External Environmental Policy. Springer, pp. 275-295

UNFCCC. (2018): The Paris agreement

Westerlund J (2007): Testing for error correction in panel data. Oxford Bulletin of Economics and statistics 69, 709-748

Westerlund J, Thuraisamy K, Sharma S (2015): On the use of panel cointegration tests in energy economics. Energy Economics 50, 359-363

Xu B, Lin B (2016a): A quantile regression analysis of China's provincial CO2 emissions: Where does the difference lie? Energy Policy 98, 328-342

Xu B, Lin B (2016b): Regional differences of pollution emissions in China: Contributing factors and mitigation strategies. Journal of Cleaner Production 112, 1454-1463

Yasmeen R, Li Y, Hafeez M, Ahmad H (2018): The trade-environment nexus in light of governance: a global potential. Environmental Science and Pollution Research 25, 3436034379

Yii K-J, Bee K-Y, Cheam W-Y, Chong Y-L, Lee C-M (2018): Is transportation infrastructure important to the One Belt One Road (OBOR) Initiative? Empirical evidence from the selected Asian countries. Sustainability 10, 4131

Zhang C (2021): The EU-China energy cooperation: toward a reciprocal partnership? Asia Europe Journal, 1-15

Zhang L, Gao J (2016): Exploring the effects of international tourism on China's economic growth, energy consumption and environmental pollution: Evidence from a regional panel analysis. Renewable and Sustainable Energy Reviews 53, 225-234

Zhang N, Liu Z, Zheng X, Xue J (2017a): Carbon footprint of China's belt and road. Science $357,1107-1107$

Zhang X, Zhao X, Jiang Z, Shao S (2017b): How to achieve the 2030 CO2 emission-reduction targets for China's industrial sector: retrospective decomposition and prospective trajectories. Global environmental change 44, 83-97 
685

686

687

688

689

690

Zhang Y-J, Sun Y-F, Huang J (2018): Energy efficiency, carbon emission performance, and technology gaps: Evidence from CDM project investment. Energy Policy 115, 119-130

Zhao X, Zhang X, Shao S (2016): Decoupling CO2 emissions and industrial growth in China over 1993-2013: the role of investment. Energy Economics 60, 275-292 


\section{Figures}

Chinese investments in Belt and Road Initiative (BRI) countries 2013- H1 2020 (million USD)

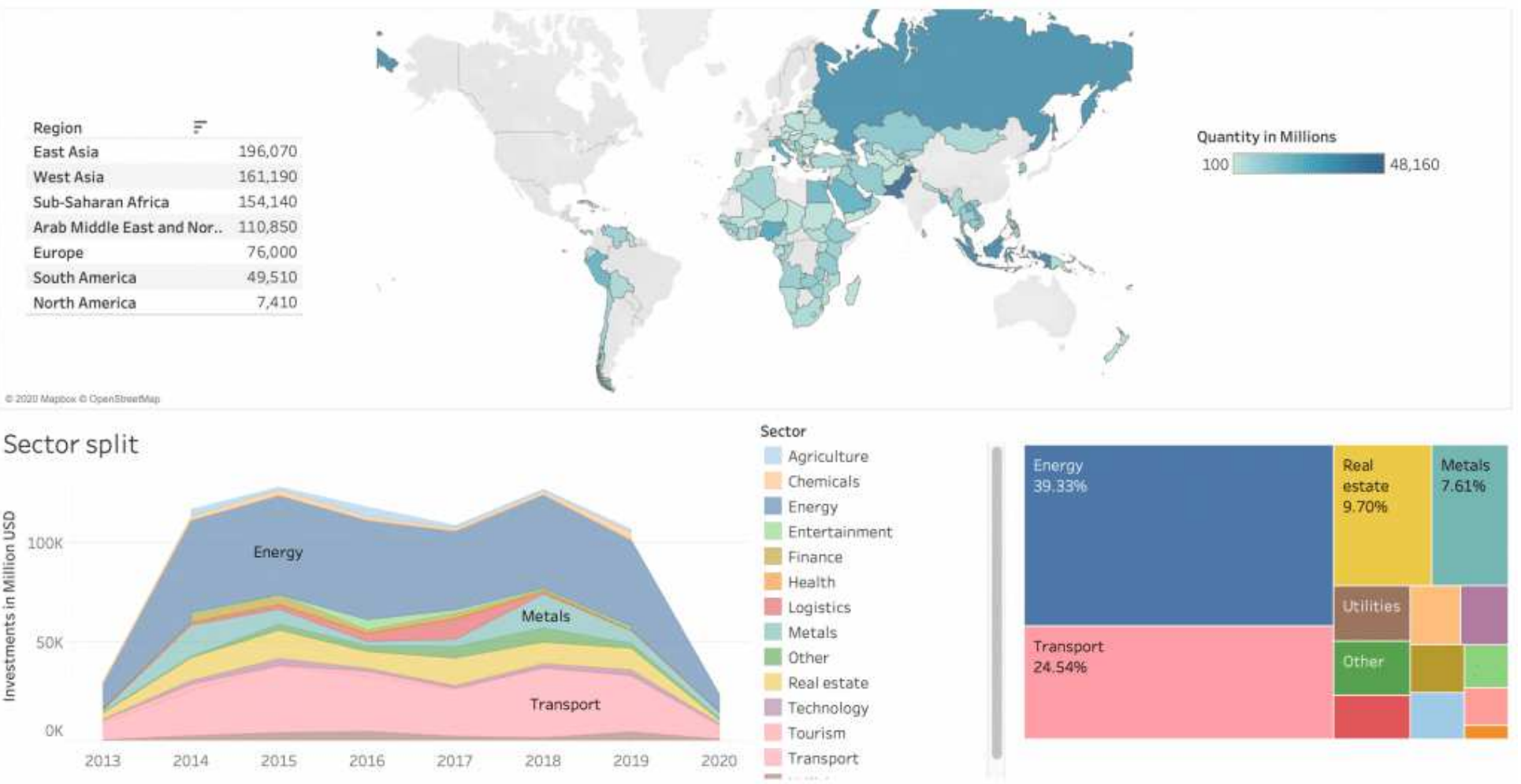

(c) Copyright 2020 Green BRI Center, International institute of Green Finance (IIGF), Beijing Data:American Enterprise Institute (AEI). China Investment Tracker, 2020

\section{Figure 1}

Investments of China in BRI countries from 2013-H12020 (million USD) 1 Note: The designations employed and the presentation of the material on this map do not imply the expression of any opinion whatsoever on the part of Research Square concerning the legal status of any country, territory, city or area or of its authorities, or concerning the delimitation of its frontiers or boundaries. This map has been provided by the authors. 